Article

\title{
Effects of Br substituent on catalytic performance of Ru-bda (H2bda = 2,2'-bipyridine-6,6'-dicarboxylic acid) catalysts for water oxidation
}

\author{
Zhao Liu, Yan Gao*, Ze Yu, Min Zhang, Jianhui Liu\# \\ Institute of Artificial photosynthesis, State Key Laboratory of Fine Chemicals, Dalian University of Technology, Dalian 116024, Liaoning, China
}

\section{A R T I C L E I N F O}

Article history:

Received 8 April 2015

Accepted 18 May 2015

Published 20 October 2015

\section{Keywords:}

Water oxidation

Ruthenium-bda catalyst

Bromine modification

Electronic effect

Kinetic studies

\section{A B S T R A C T}

A series of new Ru-bda catalysts with $\mathrm{Br}$ modification on the equatorial ligand, $\left[\mathrm{Ru}(\mathbf{L n})(\text { picoline })_{2}\right]$ $\left(\mathbf{H}_{2} \mathbf{L 1}=4-B r-2,2^{\prime}\right.$-bipyridine-6,6'-dicarboxylic acid (4-Br-bda), $2 ; \mathbf{H}_{2} \mathbf{L} \mathbf{2}=4,4^{\prime}$-diBr-bda, 3) and $\left.[\mathrm{Ru}(\mathbf{L 1}) \text { (isoquinoline) })_{2}\right] \mathbf{5}$, were synthesized for catalytic water oxidation. Compared with the un-substituted catalysts, the catalysts modified with $\mathrm{Br}$ displayed a marked change in the catalytic activities and reaction orders. The results confirm that the electronic effect of $\mathrm{Br}$ has a large effect on the kinetics and leads to the change in reaction orders.

(C) 2015, Dalian Institute of Chemical Physics, Chinese Academy of Sciences. Published by Elsevier B.V. All rights reserved.

[20-22], Fe [23], and Ru [24-26] have been developed as highly efficient catalysts with relatively high turnover numbers and turnover frequencies.

In recent years, a family of $\mathrm{Ru}(\mathrm{bda})(\mathrm{L})_{2} \quad\left(\mathrm{H}_{2} \mathrm{bda}=\right.$ 2,2'-bipyridine-6,6'-dicarboxylic acid, $\mathrm{L}=\mathrm{N}$-donor ligands) catalysts have been developed and displayed an unprecedentedly high efficiency. Based on the catalytic center of Ru-bda, many derivants have been designed with different axial ligands. These studies revealed that the application of axial ligands with an electron withdrawing substituent improved the catalytic activities on water oxidation. These results illustrate that the catalytic activities were sensitive to the environment of their ligands [27-29]. Whereas, other studies focused on different axial ligands, we introduced electron withdrawing groups on

\footnotetext{
* Corresponding author. Tel: +86-411-84986249; Fax: +86-411-84986245; E-mail: dr.gaoyan@dlut.edu.cn

\# Corresponding author. Tel: +86-411-84986249; Fax: +86-411-84986245; E-mail: liujh@dlut.edu.cn.

This work was supported by the National Basic Research Program of China (973 program) (2014CB239402), the National Natural Science Foundation of China (20923006, 21120102036, 21106015, 91233201), and the Fundamental Research Funds for the Central Universities (DUT13RC(3)103, DUT15LK08).

DOI: 10.1016/S1872-2067(15)60895-6 | http://www.sciencedirect.com/science/journal/18722067 | Chin. J. Catal., Vol. 36, No. 10, October 2015
} 
the equatorial ligand to investigate the change in catalytic activities. Three new catalysts, $[\mathrm{Ru}(\mathbf{L 1})($ pic) 2$](2),[\operatorname{Ru}(\mathbf{L 2})($ pic) 2$]$ (3) and [Ru(L1)(isoq)2] (5) (H2L1 = 4-Br-2,2'-bipyridine-6,6'dicarboxylic acid; $\mathbf{H}_{2} \mathbf{L} \mathbf{2}=4,4^{\prime}$-diBr-2,2' -bipyridine-6,6'-dicarboxylic acid) were synthesized and are shown in Fig. 1 and Scheme 1. The effects of electron withdrawing groups on catalytic water oxidation activities and the corresponding mechanisms are studied and discussed in this paper.
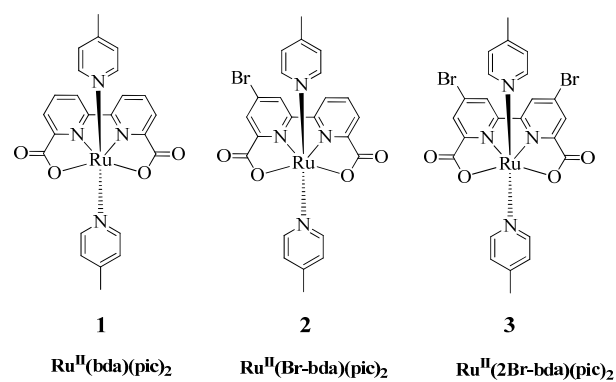

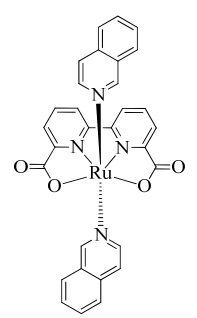

4

Ru"(bda)(isoq) 2

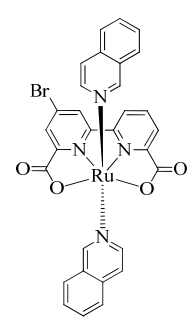

5

Rü(Br-bda)(isoq)
Fig. 1. Structures of catalysts 1-5. Ru ${ }^{\mathrm{II}}(\mathrm{bda})(\mathrm{pic})_{2} \mathbf{1} ; \mathrm{Ru}^{\mathrm{II}}(\mathrm{Br}-\mathrm{bda})(\mathrm{pic})_{2}$

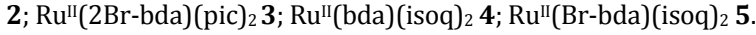

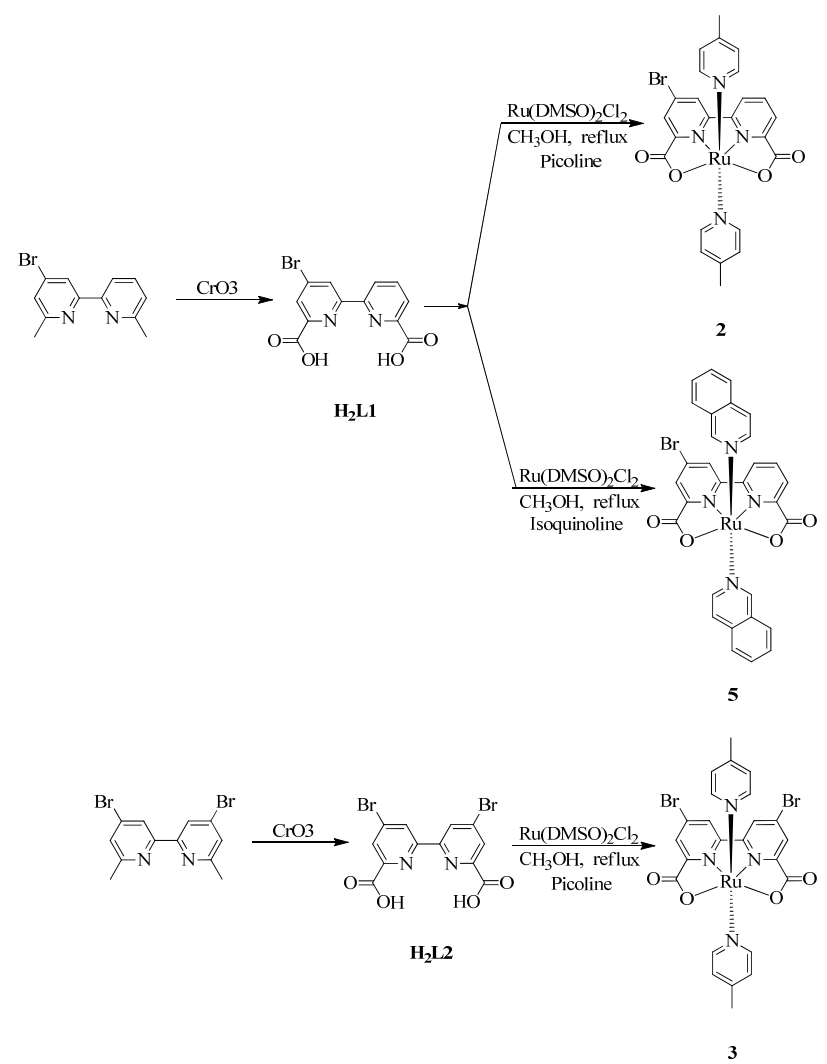

Scheme 1. Synthetic routes for the preparation of complexes 2, 3 and 5.

\section{Experimental}

\subsection{Methods}

Cyclic voltammetry (CV) and differential pulse voltammetry (DPV) were recorded on an IJCambria CHI-660 potentiostat or a Bro-Logic SP-150 potentiostat using a three-electrode setup. $\mathrm{CV}$ measurements were carried out at a scan rate of $100 \mathrm{mV} / \mathrm{s}$. DPV experiments were carried out with the parameters: pulses height $=50 \mathrm{mV}$, pulses width $=50 \mathrm{~ms}$, step high $=4 \mathrm{mV}$. A glass carbon electrode ( $2 \mathrm{~mm}$ in diameter) was used as a working electrode, a platinum wire as an auxiliary electrode, and an $\mathrm{Ag} / \mathrm{AgCl}$ electrode as a reference electrode. The $\mathrm{CVs}$ were ob-

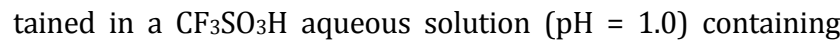
$33 \%$ of $\mathrm{CF}_{3} \mathrm{CH}_{2} \mathrm{OH}$. [Ru(bpy) $]^{2+}$ was used as a reference with the $E_{1 / 2}\left(\mathrm{Ru}^{\mathrm{II}} / \mathrm{Ru}^{\mathrm{III}}\right)$ being $1.26 \mathrm{~V}$ vs. NHE.

The Pourbaix diagrams were obtained in an aqueous Britton-Robinson buffer solution ( $0.1 \mathrm{~mol} / \mathrm{L})$ containing catalysts (1.0 mmol/L) in the $\mathrm{pH}$ range of $1.5-10$. The $\mathrm{pH}$ values of the solutions were adjusted by the addition of an aqueous $\mathrm{NaOH}$ solution $(0.2 \mathrm{~mol} / \mathrm{L})$.

The oxygen evolution was recorded with an oxygen sensor (Ocean Option, Oxygen Sensing System, NEFOX-GT, NFGO 540), and the concentration of oxygen was calibrated by gas chromatography (GC-2014 Shimadzu) equipped with a thermal conductive detector, a 5 A molecular sieve column and with $\mathrm{Ar}$ as a carrier gas.

To determine the kinetic order, we recorded oxygen evolution as a function of time at the initial stages of the reactions by adding $1.5 \mathrm{mmol} / \mathrm{L} \mathrm{Ce(IV)} \mathrm{oxidant} \mathrm{to} \mathrm{solutions} \mathrm{containing}$ $0.2-6.0 \mu \mathrm{mol} / \mathrm{L}$ of the catalyst. The reaction orders of catalysts were determined by plotting the initial logarithmic [rate] vs. logarithmic [Ru]. All the experiments were carried out in a 0.1 mol/L aqueous triflic acid solution at $25{ }^{\circ} \mathrm{C}$ with a total volume of $2 \mathrm{~mL}$. Ultraviolet visible-Vis data were obtained using a Cary 300 Bio UV-Vis spectrophotometer.

\subsection{Materials and syntheses}

All chemicals and solvents were purchased from Sigma-Aldrich (St. Louis, MO, USA). All synthetic reactions were carried out under an $\mathrm{N}_{2}$ atmosphere. The compounds $\mathrm{Ru}(\mathrm{DMSO})_{4} \mathrm{Cl}_{2}, 2,2^{\prime}$-bipyridine-6,6'-dicarboxylic acid, 4- $\mathrm{Br}-6,6^{\prime}$ dimethyl-2,2'-bipyridine, and 4,4'-diBr-6,6'-dimethyl-2,2'- bipyridine were prepared according to the procedures reported in the literature [30-33]. All the chemicals used are commercially available.

\subsubsection{Synthesis of 4-Br-6, 6'-dicarboxylic acid-2, 2'-bipyridine ( $\left.\mathrm{H}_{2} \mathrm{L1}\right)$}

4-Br-6,6'-dimethyl-2,2'-bipyridine (262 $\mathrm{mg}, 1 \mathrm{mmol}$ ) was added in portions to a solution of $95 \% \mathrm{H}_{2} \mathrm{SO}_{4}(10 \mathrm{~mL})$ containing $\mathrm{CrO}_{3}\left(600 \mathrm{mg}, 6 \mathrm{mmol}\right.$ ) and heated to $80{ }^{\circ} \mathrm{C}$ for $5 \mathrm{~h}$. After cooling the mixture to room temperature, the dark green solution was poured into $200 \mathrm{~mL}$ of ice-cold water. The precipitate was filtered and washed with cool water. The desired product was obtained as white powder with a yield of $81 \%$. ${ }^{1} \mathrm{H}$ NMR 
(CD $\left.{ }_{3} \mathrm{OD}, 400 \mathrm{MHz}\right): \delta 9.02(\mathrm{~s}, \mathrm{~J}=1.6,1 \mathrm{H}), 8.72(\mathrm{~d}, \mathrm{~J}=6.6,1 \mathrm{H})$, $8.28(\mathrm{~s}, \mathrm{~J}=1.6,1 \mathrm{H}), 8.26-8.20(\mathrm{~m}, 1 \mathrm{H}), 8.19(\mathrm{~d}, \mathrm{~J}=6.7,1 \mathrm{H})$. HRMS (ESI): found $m / z=322.9584[\mathrm{M}+\mathrm{H}]^{+}$, calcd.: 322.9589 .

\subsubsection{Synthesis of 4, 4'-diBr-6, 6'-dicarboxylic acid-2, 2'-bipyridine ( $\left.\mathbf{H}_{2} \mathbf{L} 2\right)$}

Using the same synthesis and purification methods of compound L1, compound L2 was obtained as a white solid with a yield of $67.5 \%$. ${ }^{1} \mathrm{H}$ NMR (CD $30 D, 400 \mathrm{MHz}$ ): $\delta 8.71(\mathrm{~s}, 2 \mathrm{H}), 7.36$ (s, 2H). HRMS (ESI): found $m / z=401.9950[\mathrm{M}+\mathrm{H}]^{+}$, calcd.: 401.9954 .

\subsubsection{Synthesis of [Ru(II) L1(picoline) 2$]$ (2)}

A mixture of 4-Br-2,2'-bipyridine-6,6'-dicarboxylic acid (322 $\mathrm{mg}, 1.0 \mathrm{mmol})$, cis-[Ru(DMSO) $\left.{ }_{4} \mathrm{Cl}_{2}\right]$ (484 mg, $\left.1.0 \mathrm{mmol}\right)$ and $\mathrm{Et}_{3} \mathrm{~N}(0.8 \mathrm{~mL})$ in methanol $(20 \mathrm{~mL})$ was degassed with $\mathrm{N}_{2}$ and refluxed over $3 \mathrm{~h}$. An excess of 4-picoline was added, and the solution was refluxed for an additional $16 \mathrm{~h}$. Solvents were removed, and the resulting mixture was purified by column chromatography on a silica gel with methanol as the eluent. Complex 2 was obtained as a dark red solid with a yield of $35 \%$. ${ }^{1} \mathrm{H} \mathrm{NMR}\left(\mathrm{CDCl}_{3}, 400 \mathrm{MHz}\right): \delta 8.87(\mathrm{~s}, 1 \mathrm{H}), 8.19$ (s, 1H), 8.11 (d, J $=6.5,1 \mathrm{H}), 8.04(\mathrm{~d}, \mathrm{~J}=7.8,1 \mathrm{H}), 7.89(\mathrm{t}, \mathrm{J}=8.0,1 \mathrm{H}), 7.64(\mathrm{~d}, \mathrm{~J}=$ 6.5, 4H), $7.06(\mathrm{~d}, \mathrm{~J}=5.6,4 \mathrm{H}), 2.25(\mathrm{~d}, \mathrm{~J}=4.02,6 \mathrm{H})$. HRMS (ESI): found $m / z=608.9699[\mathrm{M}+\mathrm{H}]^{+}$, calcd.: 608.9711 .

\subsubsection{Synthesis of [Ru(II)L2(picoline) 2$]$ (3)}

Using the same synthesis and purification methods of complex 2, complex 3 was obtained as a red solid with a yield of 26\%. ${ }^{1} \mathrm{H}$ NMR (CD $\left.3 \mathrm{OD}, 400 \mathrm{MHz}\right): \delta 8.510(\mathrm{~s}, 2 \mathrm{H}), 8.150(\mathrm{~s}, 2 \mathrm{H})$, $7.57(\mathrm{~d}, \mathrm{~J}=5.1,4 \mathrm{H}), 6.92(\mathrm{~d}, \mathrm{~J}=5.3,4 \mathrm{H}), 2.30$ (s, 6H). HRMS (ESI): found $m / z=686.8815[\mathrm{M}+\mathrm{H}]^{+}$, calcd.: 686.8817 .

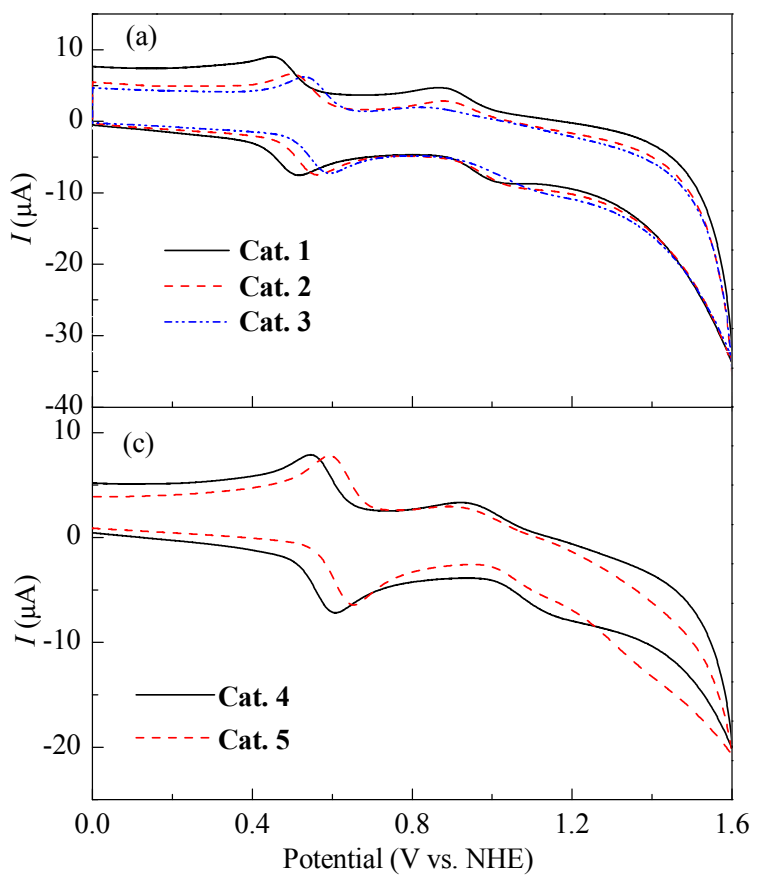

\subsubsection{Synthesis of [Ru(II)L1(isoquinoline) 2$]$ (5)}

Using the same synthesis and purification methods of complex 2, complex 5 was obtained as a red solid with a yield of 33\%. ${ }^{1} \mathrm{H} \mathrm{NMR}\left(\mathrm{CD}_{3} \mathrm{OD} / \mathrm{CDCl}_{3}, 400 \mathrm{MHz}\right): \delta 8.92$ (s, $\left.1 \mathrm{H}\right), 8.28$ (s, $2 \mathrm{H}), 8.19$ (s, 1H), $8.11(\mathrm{~d}, \mathrm{~J}=6.5,1 \mathrm{H}), 8.04(\mathrm{~d}, \mathrm{~J}=7.8,1 \mathrm{H}), 7.89$ $(\mathrm{t}, \mathrm{J}=8.0,1 \mathrm{H}), 7.60(\mathrm{~d}, \mathrm{~J}=6.55,2 \mathrm{H}), 7.39-7.35(\mathrm{~m}, \mathrm{~J}=5.65,4 \mathrm{H})$, $7.28(\mathrm{t}, 2 \mathrm{H}), 7.20-7.16(\mathrm{~m}, 4 \mathrm{H}), 7.08(\mathrm{~d}, 2 \mathrm{H})$. HRMS (ESI): found $m / z=680.9715[\mathrm{M}+\mathrm{H}]^{+}$, calcd.: 680.9711 .

\section{Results and discussion}

\subsection{Electrochemistry}

The CVs and DPVs of complexes 1-5 were measured in a mixed aqueous solution of $\mathrm{CF}_{3} \mathrm{CH}_{2} \mathrm{OH} / \mathrm{H}_{2} \mathrm{O}(1 / 2, \mathrm{v} / \mathrm{v}, \mathrm{pH}=1.0)$ with $\mathrm{Ag} / \mathrm{AgCl}(3.0 \mathrm{~mol} / \mathrm{L}, \mathrm{KCl})$ electrode as the reference electrode and $\mathrm{Pt}$ wire as the counter electrode and are shown in Fig. 2. Detailed electrochemical data of these complexes are shown in Table 1. Complexes 1-5 displayed two redox waves from 0.4 to $1.1 \mathrm{~V}$ (vs. NHE) in the CV measurements (Fig. 2(a) and 2(c)). The first reversible peaks from 0.4 to $0.6 \mathrm{~V}$ are assigned to $\mathrm{Ru}^{\mathrm{II}} /\left[\mathrm{Ru}^{\mathrm{III}}-\mathrm{OH}_{2}\right]^{+}$redox couples. The other reversible couples at about $1.0 \mathrm{~V}$ (vs. NHE) are assigned to $\left[\mathrm{Ru}^{\mathrm{III}}-\mathrm{OH}_{2}\right]^{+} /\left[\mathrm{Ru}^{\mathrm{IV}}-\mathrm{OH}\right]^{+}$redox couples. The electronic effect of $\mathrm{Br}$ substituent on the equatorial ligand results in the anodic shift of the oxidation potentials of $\mathrm{Ru}^{\mathrm{II}} / \mathrm{Ru}^{\mathrm{III}}$ and $\mathrm{Ru}^{\mathrm{III}} / \mathrm{Ru}^{\mathrm{IV}}$ couples.

The DPV studies of complexes 1-5 show similar results to those of the CVs. The DPV curves are shown in Figure $2 \mathrm{~b}$ and $2 \mathrm{~d}$. Another redox wave at $1.2 \mathrm{~V}$ is assigned to the $\mathrm{Ru} / \mathrm{IV} / \mathrm{Ru}^{\mathrm{V}}$ redox couples of complexes $\mathbf{3}$ and $\mathbf{5}$. For the Ru-bda catalysts, a catalytic current is expected after $\left[\mathrm{Ru}^{\mathrm{V}}=0\right]^{+}$was generated, but

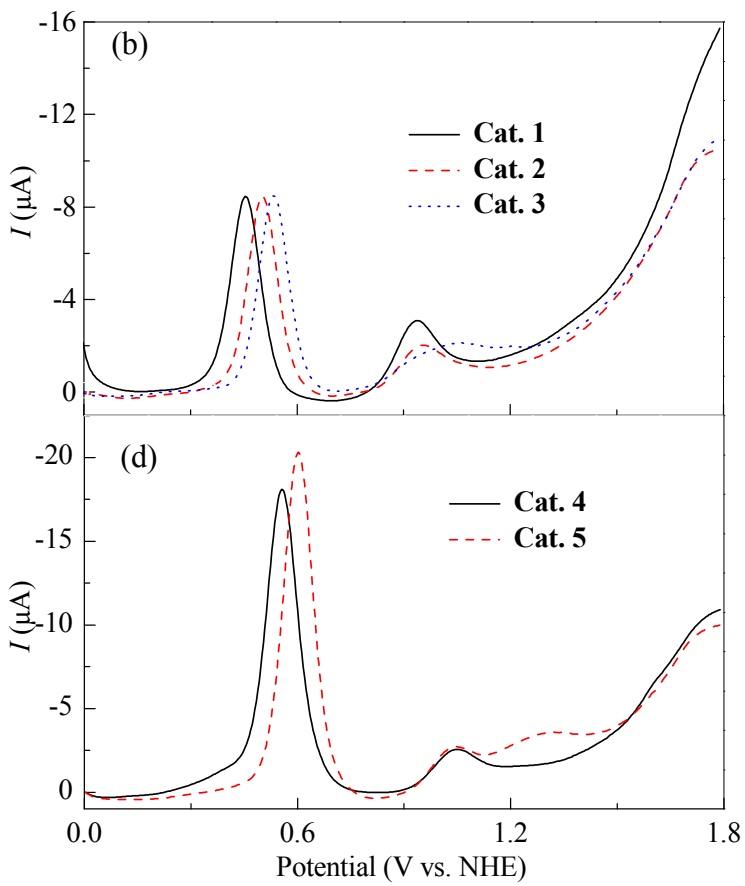

Fig. 2. (a) Cyclic voltammograms (CVs) of complexes 1-3. (b) Differential pulse voltammograms (DPVs) of complexes 1-3. (c) CVs of complexes 4 and 5. (d) DPVs of complexes 4 and 5. (Conditions: [catalyst] $=1.0 \mathrm{mM}$, a mixed $\mathrm{CF}_{3} \mathrm{CH}_{2} \mathrm{OH} / \mathrm{H}_{2} \mathrm{O}\left(\mathrm{v} / \mathrm{v}=1 / 2, \mathrm{pH}=1.0\right.$ ) as solvent, scan rate $=100 \mathrm{mVs}{ }^{-1}$, $\mathrm{Ag} / \mathrm{AgCl}\left(3.0 \mathrm{M}, \mathrm{KCl}\right.$, aqueous) as the reference electrode and $E_{\mathrm{NHE}}=E_{\mathrm{Ag} / \mathrm{AgCl}}+0.21 \mathrm{~V}$. 
Table 1

Redox potentials of complexes 1-5.

\begin{tabular}{|c|c|c|c|c|}
\hline Cat. & $\begin{array}{c}E_{1 / 2}\left(\mathrm{Ru}^{\mathrm{II} / \mathrm{III}}\right) \\
\left(\mathrm{V} \text { vs. NHE }{ }^{\mathrm{a}}\right) \\
\end{array}$ & $\begin{array}{c}E_{1 / 2}\left(\mathrm{Ru}^{\mathrm{III} / \mathrm{IV}}\right) \\
(\mathrm{V} \text { vs. NHEa) }\end{array}$ & $\begin{array}{c}E_{1 / 2}\left(\mathrm{Ru}^{\mathrm{IV} / \mathrm{V}}\right) \\
(\mathrm{V} \text { vs. NHE })\end{array}$ & $\begin{array}{c}E_{\text {onset }} \\
\text { (V vs. NHE a) }\end{array}$ \\
\hline 1 & 0.458 & 0.938 & - & 1.070 \\
\hline 2 & 0.502 & 0.954 & - & 1.080 \\
\hline 3 & 0.534 & 1.066 & 1.180 & 1.190 \\
\hline 4 & 0.556 & 1.040 & - & 1.240 \\
\hline 5 & 0.600 & 1.052 & 1.250 & 1.270 \\
\hline
\end{tabular}

Reaction conditions: $\mathrm{CF}_{3} \mathrm{SO}_{3} \mathrm{H}(\mathrm{pH}=1.0) / \mathrm{CF}_{3} \mathrm{CH}_{2} \mathrm{OH}=2 / 1 \mathrm{~mL} / \mathrm{mL}$, reaction temperature $20^{\circ} \mathrm{C}$.

${ }^{\mathrm{a}} \mathrm{Ru}(\mathrm{bpy}){ }_{3}{ }^{2+}$ was used as a reference with $E_{1 / 2}=1.26 \mathrm{~V}$ vs. NHE.

the active intermediate $\left[\mathrm{Ru}^{\mathrm{V}}=0\right]^{+}$can be overlapped by the catalytic current of a more active catalyst that cannot be captured. In addition, complexes $\mathbf{2}$ and $\mathbf{3}$ exhibited lower catalytic currents than complex $\mathbf{1}$, indicating that the catalytic efficiency of catalyst $\mathbf{1}$ was slightly higher than those of $\mathbf{2}$ and $\mathbf{3}$. A similar trend was also displayed by $\mathbf{4}$, showing a slightly higher efficiency than that of $\mathbf{5}$. The electrochemical data suggest that the Br substituent causes an anodic shift of the oxidation potentials of catalysts, and the onset potentials of catalytic water oxidations.

The Pourbaix diagrams ( $E_{1 / 2}$ vs $\left.\mathrm{pH}\right)$ of complexes $\mathbf{2}, \mathbf{3}$ and $\mathbf{5}$ were studied by DPV in aqueous Britton-Robinson buffer solutions at different $\mathrm{pH}$ values (2-10) and are shown in Fig. 3. Similar to the reported results of catalysts 1 and 4 [34-36], the segments of $\mathrm{Ru}$ species of different valency are divided by the redox potential verses $\mathrm{pH}$ lines. The redox processes of $\mathrm{Ru}^{\mathrm{II}} / \mathrm{Ru}^{\mathrm{III}}, \mathrm{Ru}^{\mathrm{III}} / \mathrm{Ru}^{\mathrm{IV}}$ and $\mathrm{Ru}^{\mathrm{IV}} / \mathrm{Ru}^{\mathrm{V}}$ of these complexes occurred in a large $\mathrm{pH}$ range [37]. The $\mathrm{Ru}^{\mathrm{II}} / \mathrm{Ru}^{\mathrm{III}}$ oxidation process of catalyst 2 involves electron transfer at $\mathrm{pH}<6.2$ (slope $=0 \mathrm{mV}$ ) and accompanies proton-coupled electron transfer at $6.2<\mathrm{pH}$ $<10$ (slope $=52 \mathrm{mV} / \mathrm{pH}$ ). The subsequent oxidation process is accompanied with a single-proton-coupled electron transfer $\left(\mathrm{Ru}^{\mathrm{III}} / \mathrm{Ru}^{\mathrm{IV}}\right)$ at $2<\mathrm{pH}<10$ (slope $\left.=42 \mathrm{mV} / \mathrm{pH}\right)$. Further oxidation from $\left[\mathrm{Ru}^{\mathrm{IV}}=\mathrm{O}\right]^{+}$to $\left[\mathrm{Ru}^{\mathrm{V}}=\mathrm{O}\right]^{+}$only involves electron transfer as expected, whereas the oxidation of $\left[\mathrm{Ru}^{\mathrm{IV}}-\mathrm{OH}\right]+$ is accompanied by proton transfer.

The potential/pH diagrams for complexes $\mathbf{3}$ and $\mathbf{5}$ display almost identical variation trends relative to that of complex 2 . The introduction of $\mathrm{Br}$ substituent groups results in the en-

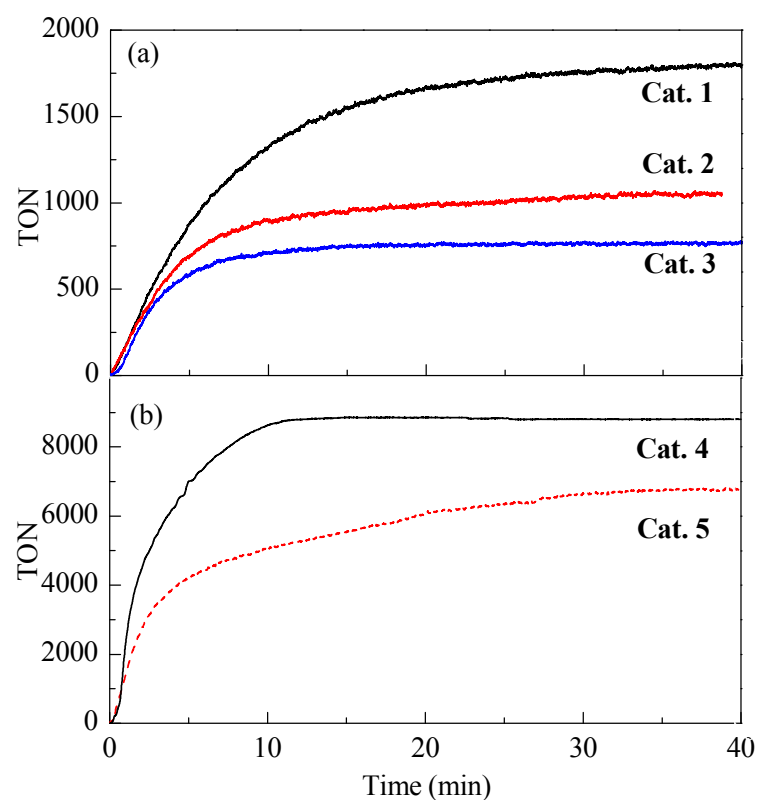

Fig. 4. Oxygen evolution curves for catalysts 1-5. (a) $5.88 \times 10^{-5} \mathrm{~mol} / \mathrm{L}$ of catalysts 1-3; (b) $1.5 \times 10^{-5} \mathrm{~mol} / \mathrm{L}$ of catalysts $\mathbf{4}$ and $\mathbf{5}$. Conditions: 3.4 $\mathrm{mL}$ of aqueous solution $\left(0.1 \mathrm{~mol} / \mathrm{L} \mathrm{CF}_{3} \mathrm{SO}_{3} \mathrm{H}, \mathrm{pH}=1.0\right)$ containing 0.526 $\mathrm{mol} / \mathrm{L}$ of $\mathrm{Ce}^{\mathrm{IV}}$.

hanced electron withdrawing ability of the equatorial ligands and leads to a more positive potential deflection of the four segments of $\mathrm{Ru}$ species. However, the redox potential of the $\mathrm{Ru}^{\mathrm{IV}} / \mathrm{Ru}^{\mathrm{V}}$ wave is not clear in catalyst $\mathbf{3}$ at $\mathrm{pH}<\mathbf{5}$, possibly because the catalyst was deposited on the electrode surface. We conclude that the electron withdrawing groups on the equatorial ligand substantially increase the redox potential of catalysts $\mathbf{2}, \mathbf{3}$, and $\mathbf{5}$ in an acidic solution. Therefore, the redox processes of complexes $\mathbf{2}, \mathbf{3}$, and $\mathbf{5}$ at $\mathrm{pH} 1.0$ are proposed to be [Rull $\rightarrow$ $\left[\mathrm{Ru}^{\mathrm{III}}-\mathrm{OH}_{2}\right]^{+} \rightarrow\left[\mathrm{Ru}^{\mathrm{IV}}-\mathrm{OH}\right]^{+} \rightarrow\left[\mathrm{Ru}^{\mathrm{V}}=\mathrm{O}\right]^{+}$before water oxidation.

\subsection{Catalytic water oxidation}

The catalytic activities for water oxidation were evaluated in aqueous solutions $(\mathrm{pH}=1.0)$ containing a catalyst and $\mathrm{Ce}^{\mathrm{IV}}$. The evolved oxygen was measured with an oxygen sensor and gas chromatography, and is shown in Fig. 4. Catalyst and Ce $\mathrm{IV}^{\mathrm{IV}}$
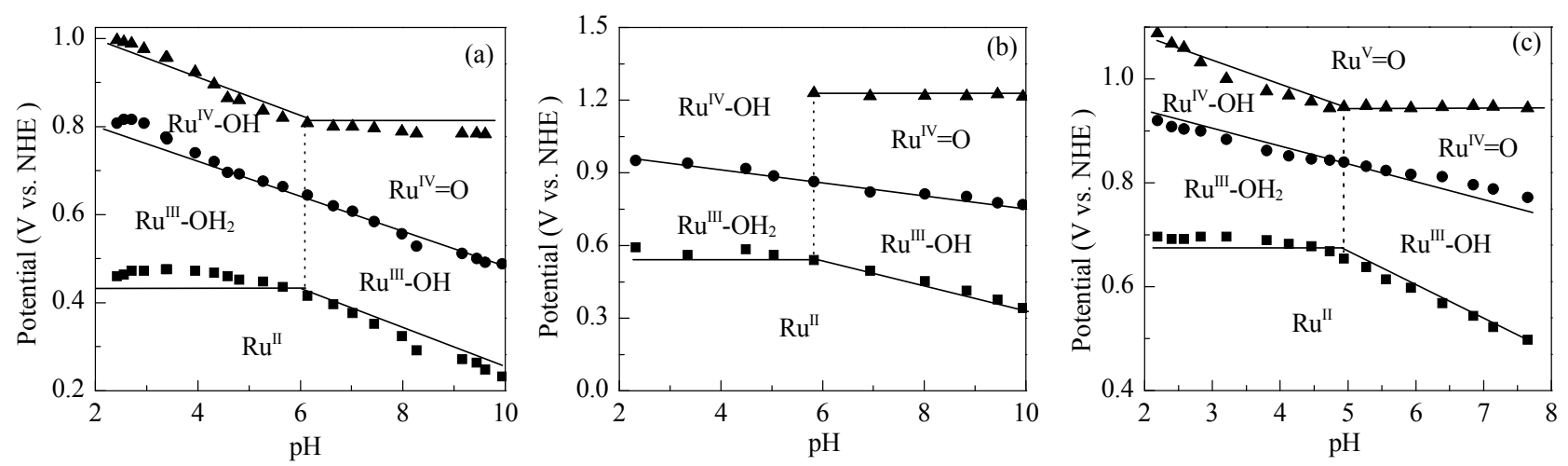

Fig. 3. Pourbaix diagrams of complexes (a) 2, (b) 3 and (c) 5. 
$(0.526 \mathrm{~mol} / \mathrm{L})$ were dissolved in $3.4 \mathrm{~mL} \mathrm{CF}_{3} \mathrm{SO}_{3} \mathrm{H}$ solution $(\mathrm{pH}=$ 1.0) containing $1 \% \mathrm{CF}_{3} \mathrm{CH}_{2} \mathrm{OH}$. The turnover numbers of catalysts 1, 2 and 3 were 1807, 1059 and 773, respectively. Under the same conditions, catalyst 1 showed a higher catalytic activity that stops increasing after $30 \mathrm{~min}$, but catalysts $\mathbf{2}$ and $\mathbf{3}$ showed lower catalytic activities. The maximum turnover frequencies of catalysts 1,2 and 3 were $4,2.5$, and $2 \mathrm{~s}^{-1}$, respectively. These results show that the catalytic abilities become less efficient after replacing the $-\mathrm{H}$ atoms with $\mathrm{Br}$ groups.

Compared with catalyst $\mathbf{4}$, a notable decrease of reaction rate and catalytic activity were observed for catalyst $\mathbf{5}$ as shown in Fig. 4(b). The turnover number of catalyst $\mathbf{5}$ was 6680, which was approximately 2000 less than the corresponding value for catalyst $\mathbf{4}$ under the same experimental conditions. The maximum turnover frequencies of catalysts 4 and 5 were 40 and $20 \mathrm{~s}^{-1}$, respectively, which also indicates the undesirable effect of $\mathrm{Br}$ groups in the catalysts. The results show that the $-\mathrm{Br}$ substituent on the equatorial ligand of catalyst $\mathbf{5}$ causes a negative effect on the catalytic activity of water oxidation.

\subsection{Kinetic studies}

Considering the catalytic water oxidation performances of complexes 1-5, the electronic effect of $\mathrm{Br}$ groups is a disadvantage. To explore the reasons of this low efficiency, kinetic studies were performed. Using $\mathrm{Ce}^{\mathrm{IV}}$ as the oxidant, we have previously demonstrated that the rate law of $\mathrm{Ce}^{\mathrm{IV}}$ consumption is zero order under low $\left[\mathrm{Ce}^{\mathrm{IV}}\right]$ conditions $\left(\left[\mathrm{Ce}^{\mathrm{IV}}\right]<2.0 \mathrm{mmol} / \mathrm{L}\right)$, whereas the mechanism of water oxidation is a bimolecular coupling reaction (second-order) in $\left[\mathrm{Ru}(\mathrm{bda})(\mathrm{L})_{2}\right](\mathrm{L}=\mathrm{N}$-donor ligands) [34,35]. As shown in Fig. 5, the kinetic measurements were carried out by monitoring the decay of the absorbance of $\mathrm{Ce}^{\mathrm{IV}}$ at a wavelength of $360 \mathrm{~nm}$ upon addition of catalysts. Cat- alysts 1-3 at concentrations of $0.8,2,4$ and $6 \mu \mathrm{mol} / \mathrm{L}$, and catalysts 4 and 5 at concentrations of $0.2,0.5,0.8$ and $1.0 \mu \mathrm{mol} / \mathrm{L}$ were injected in a $\mathrm{Ce}^{\mathrm{IV}}(1.5 \mathrm{mmol} / \mathrm{L})$ aqueous solution $(\mathrm{pH} 1.0$, containing $0.1 \mathrm{~mol} / \mathrm{L} \mathrm{CF}_{3} \mathrm{SO}_{3} \mathrm{H}$ ), and the initial rates were calculated by linear fitting the data from 2 to $10 \mathrm{~s}$. No data were collected in the first $2 \mathrm{~s}$ because of the operations for injecting the catalyst and stirring. The rate vs. [Cat.] order was estimated by tracking the slope of $\ln$ (Rate) vs. $\ln ([$ Cat.]), which are shown in Fig. 6. The slope value of catalyst $\mathbf{1}$ was 2.08. A second-order reaction process was confirmed, which agrees with our previous report. The slope values of catalysts $\mathbf{2}$ and $\mathbf{3}$ were 1.79 and 1.61 , which were lower than that of catalyst 1 . This result implies that the catalytic processes of $\mathbf{2}$ and $\mathbf{3}$ do not follow a normal second-order reaction. The lower kinetic order indicates that catalysts $\mathbf{2}$ and $\mathbf{3}$ involve first-order catalytic processes. Thus, the Br groups in the catalysts exhibit more activity as a first-order reaction process. The possible explanation is that the electronic effect of the substituted groups on the equatorial ligand influences the mechanisms of $\mathrm{O}-\mathrm{O}$ bond formation of water oxidation. The electron withdrawing effect of $\mathrm{Br}$ groups can partially change the mechanism of water oxidation from a bimolecular coupling reaction to a water nucleophilic attack reaction.

Similar to the kinetic measurements of complexes $\mathbf{2}$ and 3, the slope of catalyst $\mathbf{5}$ was $\mathbf{1 . 9 0}$, which is only slightly lower than that of catalyst $\mathbf{4}$. This result shows that catalyst $\mathbf{5}$ inclines to follow a bimolecular coupling reaction, but some follow a water nucleophilic attack reaction. The second-order kinetics of complex $\mathbf{5}$ can be explained by the fact that the water oxidation reaction is limited by the electronic effect of $\mathrm{Br}$ substituent on the equatorial ligand and the $\pi$ bond conjugated effect of isoquinoline. Based on a previous report, the $\pi$-bond conjugation effect of isoquinoline is conducive to bimolecular coupling reactions [28]. Therefore, the kinetic order reveals that the elec-
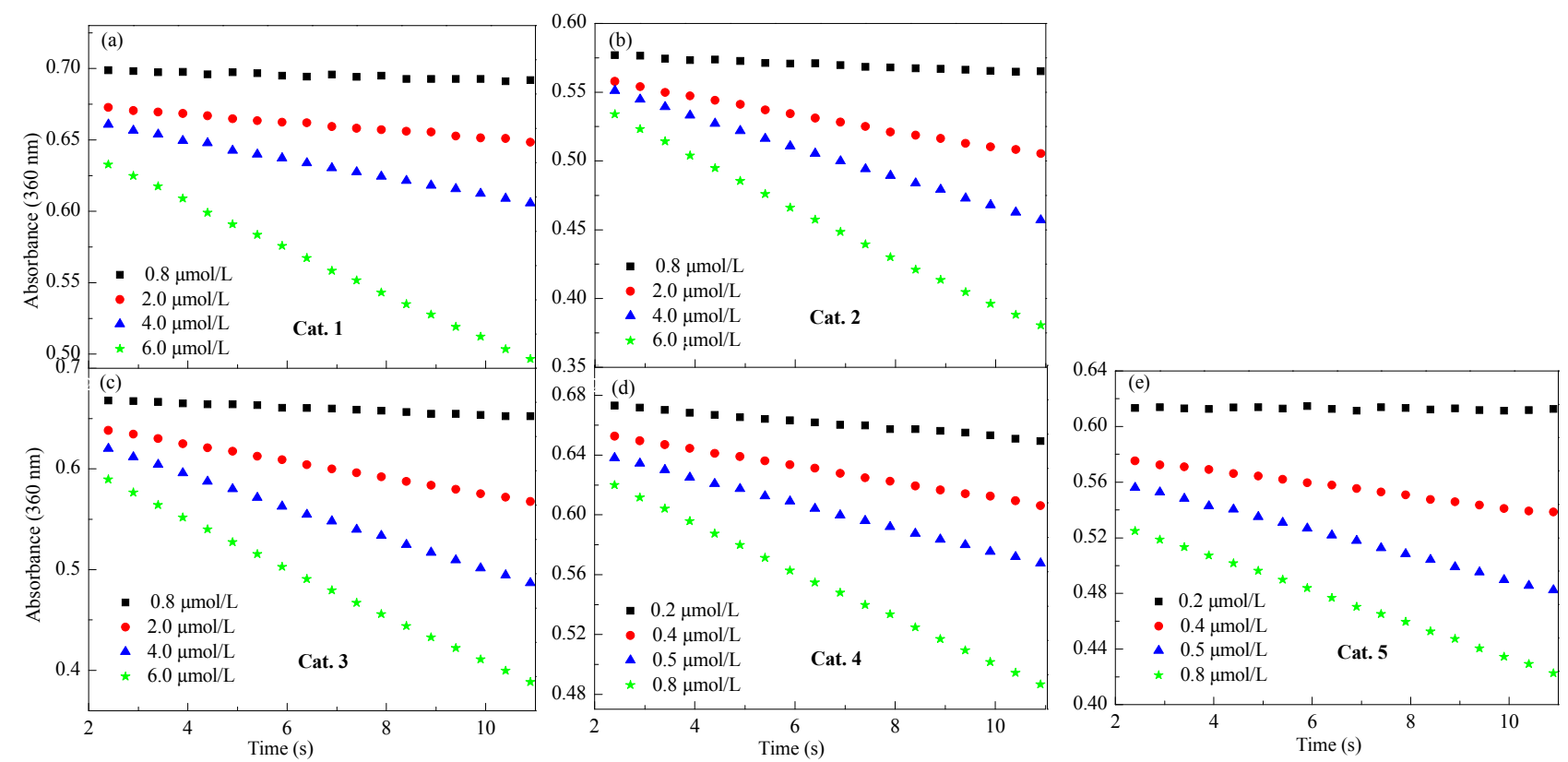

Fig. 5. $\mathrm{Ce}^{\mathrm{IV}}$ decay as monitored at $360 \mathrm{~nm}$ after the addition of different concentrations of catalysts 1-5 into a Ce $\mathrm{IV}^{\mathrm{IV}}(1.5 \mathrm{mmol} / \mathrm{L})$ aqueous solution ( $\mathrm{pH}$ 1.0 , containing $0.1 \mathrm{~mol} / \mathrm{L} \mathrm{CF}_{3} \mathrm{SO}_{3} \mathrm{H}$ ). 


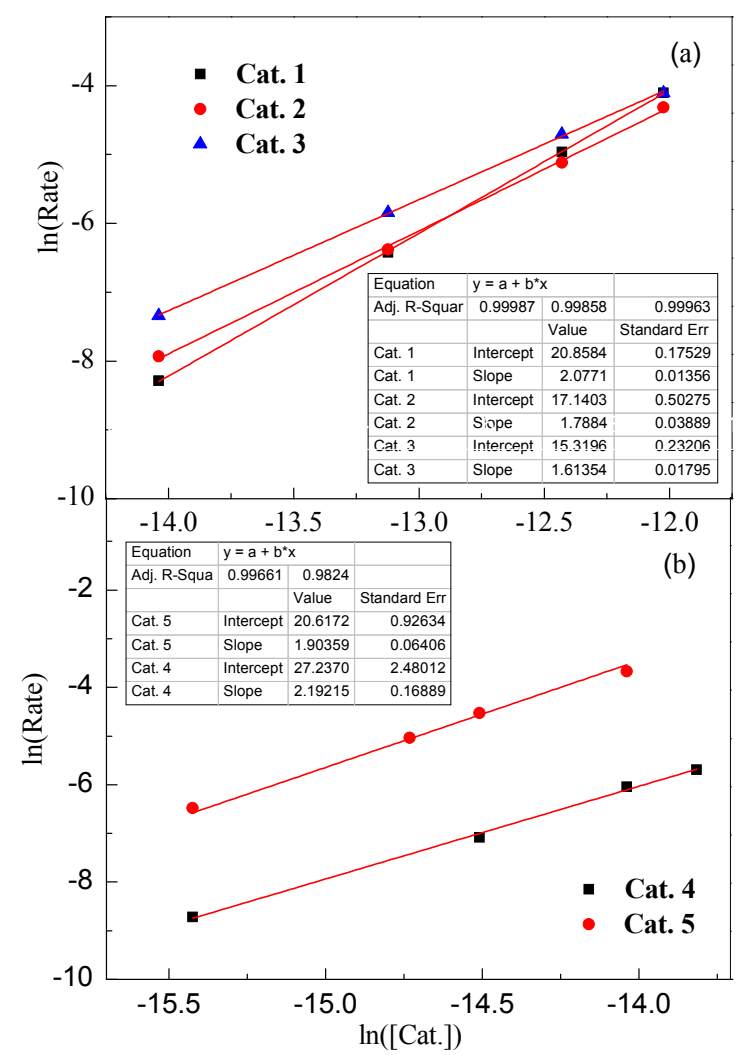

Fig. 6. Plots of $\ln \left(\right.$ Rate) vs. $\ln \left(\left[\right.\right.$ Cat.]). Kinetics of $\mathrm{Ce}^{\mathrm{IV}}$ decay by monitoring spectral change at $360 \mathrm{~nm}$ after the addition of different concentrations of catalysts into a $\mathrm{Ce}^{\mathrm{IV}}(1.5 \mathrm{mmol} / \mathrm{L})$ aqueous solution $(\mathrm{pH} 1.0$, containing $0.1 \mathrm{~mol} / \mathrm{L} \mathrm{CF}_{3} \mathrm{SO}_{3} \mathrm{H}$ ). (a) Complexes 1-3 (b) complexes 4 and 5.

tronic effect of Br substituents on the equatorial ligand in catalyst $\mathbf{5}$ is weaker than the influence of the conjugation effect isoquinoline on the mechanism of water oxidation.

\section{Conclusions}

Three new Ru-bda-based catalysts, 2, 3 and 5, were synthesized with a $\mathrm{Br}$ substituent on the bda ligands. The result demonstrates that electron withdrawing groups on the bda ligand substantially affects the performances of catalysts 2, 3 and $\mathbf{5}$ in homogeneous water oxidation systems. Higher oxidation potentials of these three catalysts were observed from CVs and DPVs than those of the un-substituted catalysts. Comparing with the un-substituted catalysts $\mathbf{1}$ and $\mathbf{4}$, the catalytic activities of 2, $\mathbf{3}$ and $\mathbf{5}$ were considerably decreased. The kinetic studies illustrate that the reaction orders gradually decrease with the increase ability of electron withdrawing groups on the equatorial ligands. Although these modified catalysts display lower catalytic water oxidation activities, this study is useful to evaluate the relationship of electronic effects and the mechanism of water oxidation.

\section{References}

[1] Blankenship R E, Tiede D M, Baber J, Bradvig G M, Fleming G, Ghiraedi M, Gunner M R, Junge W, Kramer D M, Melic A, Moore T A,
Moser C C, Nocera D G, Nozik A J, Ort D R, Parson W W, Prince R C, Sayre R T. Science, 2011, 332: 805

[2] Cox N, Retegan M, Neese F, Pantazis D A, Boussac A, Lubitz W. Science, 2014, 345: 804

[3] Barnett S M, Goldberg K I, Mayer M J. Nat Chem, 2014, 4: 498

[4] Alstrum-Acevedo J H, Brennaman M K, Meyer T J. Inorg Chem, 2005, 44: 6802

[5] Sun L, Hammarstrom L, Åkermark B, Styring S. Chem Soc Rev, 2001, 30: 36

[6] Lewis N S, Nocera D G. Proc Natl Acad Sci, 2006, 103: 15729

[7] Ruttinger W, Dismukes G C. Chem Rev, 1997, 97: 1

[8] Huynh M H, Meyer T J. Chem Rev, 2007, 107: 5004

[9] Dau H, Zaharieva I. Acc Chem Res, 2009, 42: 1861

[10] Wada T, Tsuge K, Tanaka K. Angew Chem Int Ed, 2000, 39: 1479

[11] Concepcion J, Jurss J W, Templeton J L, Meyer T J. Proceed Nat Acad Sci, 2008, 105: 17632

[12] Geletii Y V, Bogdan B, Kogerler P, Hillesheim D A, Musaev D G, Hill C L. Angew Chem Int Ed, 2008, 47: 3896

[13] Robinson D M, Go Y B, Mu M M, Gardner G, Zhang Z J, Mastrogiovanni D, Garfunkel E, Li J, Greenblatt M, Dismukes G C. J Am Chem Soc, 2013,135: 3494

[14] Mucherman J L, Polyansky D E, Wada T, Tanka K, Fujita E. Inorg Chem, 2008, 47: 1787

[15] Sala X, Maji S, Bofil R, Garcla-Anton J, Escriche L, Llobet A. Acc Chem Res, 2014, 47: 504

[16] Brimblecombe R, Dismukes G C, Swiegers G F, Spiccia L. Dalton Trans, 2009, 9374

[17] Hull J H, Balcells D, Blakemore J D, Incarvito C D, Eisenstein O, Brudvig G W, Carbtree R H.J Am Chem Soc, 2009, 131: 8730

[18] McDaniel N D, Coughlin F J, Tinker L L, Bernhard S. J Am Chem Soc, 2008, 130: 210

[19] Wasylenko D J, Ganesamoorthy G, Borau-Garcia J, Berlinguette C P. Chem Commun, 2011, 47: 4249

[20] Gao Y, Åkermark T, Liu J, Sun L, Åkermark B. J Am Chem Soc, 2009, 131: 8726

[21] Hurst J K. Coord Chem Rev, 2005, 249: 313

[22] Brimblecombe R, Swiegers G F, Dismukes G C, Spiccia L. Angew Chem Int Ed, 2008, 47: 7335

[23] Yano J, Yachandra V. Chem Rev, 2014, 114: 4175

[24] Yagi M, Kaneko M. Chem Rev, 2001, 101: 21

[25] Concepcion J J, Jurss J W, Templeton J L, Meyer T J. J Am Chem Soc, 2008, 130: 16462

[26] Zong R, Thummel R P.J Am Chem Soc, 2013, 127: 12802

[27] Duan L, Fisher A, Xu Y, Sun L. J Am Chem Soc, 2009, 131: 10397

[28] Duan L, Bozoglian F, Mandal S, Stewart B, Privalov T, Llobet A, Sun L. Nat Chem, 2012, 4: 418

[29] Jiang Y, Li F, Huang F, Zhang B B, Sun L C. Chin J Catal (姜毅, 李斐, 黄芳, 张彪彪, 孙立成. 催化学报), 2013, 34: 1489

[30] Dulière E, Deviller M, Marchand-Brynaert J. Organometallics, 2003, 22: 804

[31] Donnici C L, Maxinio Filho D H, Moreira L L C, Teixeira dox Reis G, Cordeiro E, Ferreira de Oliveira I M, Carvalho S, Paniago E B. J Braz Chem Soc, 1998, 9: 455

[32] Regnouf de J B, Papet A L, Marsura A J. J Heterocyclic Chem, 1994, 31: 1069

[33] Mukkala V M, Kankare J J. Helv Chim Acta, 1992, 75: 1578

[34] Duan L, Wang L, Inge A K, Fisher A, Zou X, Sun L. Inorg Chem, 2013, 52: 7844

[35] Duan L, Fisher A, Xue Y H, Sun L. J Am Chem Soc, 2009, 131: 10397

[36] Dovletoglou A, Adeyemi S A, Meyer T J. Inorg Chem, 1996, 35: 4120

[37] Duan L, Xu Y, Zhang P, Wang M, Sun L. Inorg Chem, 2010, 49: 209 


\title{
Graphical Abstract
}

Chin. J. Catal., 2015, 36: 1742-1749 doi: 10.1016/S1872-2067(15)60895-6

Effects of $\mathrm{Br}$ substituent on catalytic performance of $\mathrm{Ru}$-bda (H2bda = 2,2'-bipyridine-6,6'-dicarboxylic acid) catalysts for water oxidation

Zhao Liu, Yan Gao*, Ze Yu, Min Zhang, Jianhui Liu*

Dalian University of Technology
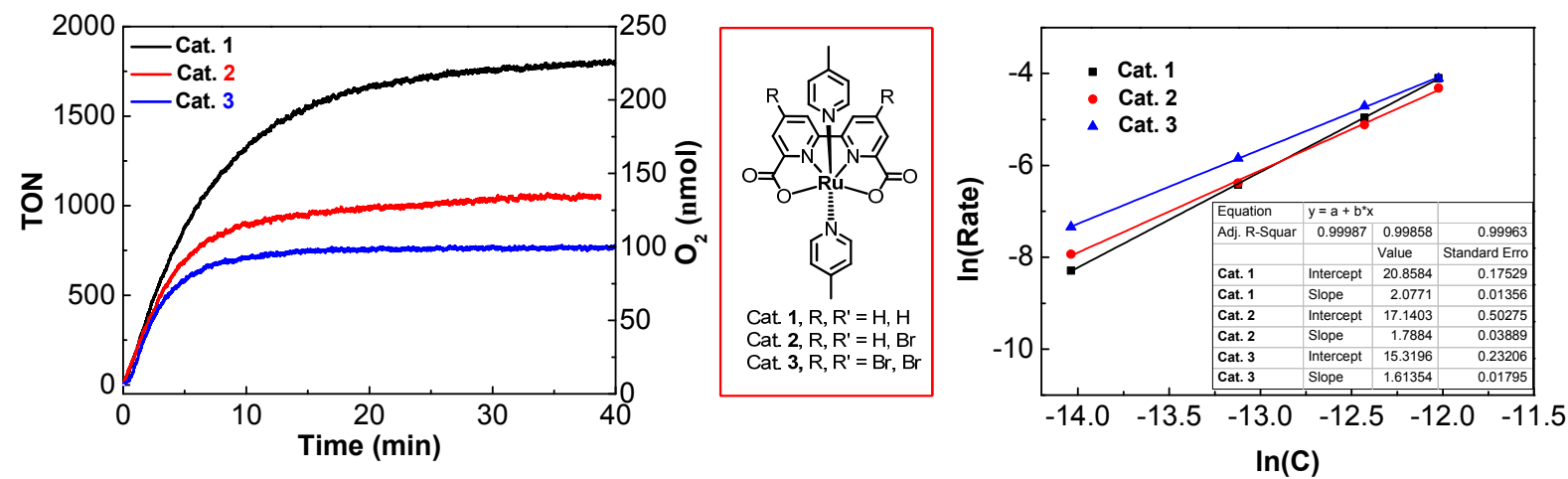

Compared with un-substituted catalysts, the Ru-bda water oxidation catalysts containing $\mathrm{Br}$ in the equatorial ligand display lower catalytic activities. The relative kinetic studies reveal the change in catalytic mechanism. All of these changes were caused by the electron withdrawing effect of $\mathrm{Br}$.

\section{溴的吸电子效应对 Ru-bda (H2bda $=2,2^{\prime}$-联吡啶-6,6' -二羧基)型催化剂 催化水氧化的性能影响}

\author{
刘 昭, 高 岩*, 于 泽, 张 敏, 刘建辉 ${ }^{*}$ \\ 大连理工大学精细化工国家重点实验室, 人工光合作用研究中心, 辽宁大连 116024
}

摘要: 太阳能高效转化和利用是实现能源结构调整、节能减排、保障社会健康发展的重要途径. 光解水制氢是实现太阳能转化成 化学能, 解决能源需求和环境污染一个理想方法, 其中水氧化反应是制约太阳能转化的关键. 近几十年来, 科学家们一直致力于 开发高效、稳定的水氧化催化剂, 以实现高效水分解获得太阳能转化为化学能所需的质子和电子. 在众多水氧化催化剂中, 基于 $\mathrm{Ru}$ 的分子催化剂因其结构简单、效果突出, 受到人们广泛关注.

本文报道了一系列Ru-bda类型的单核Ru催化剂, 通过在核心配体上进行 $B r$ 取代, 获得三个新催化剂 $2, \mathbf{3}, \mathbf{5},\left[\mathrm{Ru}(\mathbf{L n})(\text { picoline })_{2}\right]$ $\left(\mathbf{H}_{2} \mathbf{L 1}=4\right.$-澳-2,2'-联吡啶-6,6'-二羧酸(4-Br-bda), picoline = 4-甲基吡啶, $\mathbf{2} ; \mathbf{H}_{2} \mathbf{L 2}=4,4^{\prime}$-二澳-bda, 3)和 $\left.[\mathrm{Ru}(\mathbf{L 1}) \text { (isoquinoline })_{2}\right] \mathbf{5}$ (isoquinoline = 异喹啉), 并对其结构进行全面的表征. 电化学结果表明, 在核心配体中引入Br原子导致催化剂氧化中心的氧化电 位有所增加, 其原因是取代基 $\mathrm{Br}$ 的吸电子能力降低了中心金属 $\mathrm{Ru}$ 的电子云密度, 从而使其氧化电位升高. 在催化水氧化反应中, 以硝酸铈铵为氧化剂, 在 $\mathrm{pH}=1.0$ 的水溶液中对催化剂 1-5 的催化水氧化活性进行研究. 研究发现反应随着取代基 $\mathrm{Br}$ 的引入, 催化 剂催化水氧化活性逐渐降低, 说明在核心配体上的引入吸电子基团不利于Ru-bda型催化剂催化活性的提高.

为了深入了解 $\mathrm{Br}$ 取代基效应对催化剂活性的影响, 本文重点研究了催化剂1-5的动力学过程和催化水氧化机理. 在酸性条件 下, 通过利用紫外-可见吸收光谱仪研究氧化剂Ce(IV)在 $360 \mathrm{~nm}$ 处的紫外吸收变化,进而阐明催化剂催化水氧化的反应机理. 保持 氧化剂 $\mathrm{Ce}(\mathrm{IV})$ 的初始浓度为 $1.5 \mathrm{mmol} / \mathrm{L}$, 改变催化剂的浓度为 $0.1 \mu \mathrm{mol} / \mathrm{L}$ 至 $6.0 \mu \mathrm{mol} / \mathrm{L}$, 对反应最初 $10 \mathrm{~s}$ 的数据进行线性拟合和对数 计算, 分别得到的催化剂 1-5 的反应级数为 $2.08,1.79,1.61,2.19$ 和 1.90 , 这表明催化剂 $\mathbf{2}$ 和 3 与催化剂 1 的反应机理有所不同. 由于催 化剂 1 发生二级反应即在催化水氧化过程中发生双分子间的自由基耦合反应, 而催化剂 $\mathbf{2}$ 和 $\mathbf{3}$ 的反应级数均小于 2 , 说明核心配体上 的 $\mathrm{Br}$ 取代基的吸电子效应导致催化剂 $\mathbf{2}$ 和 $\mathbf{3}$ 的反应机理发生改变, 在水氧化反应过程中部分催化剂 2 和 3 分子发生了单分子反应, 即 水分子亲核进攻机理. 当轴向配体由 4 -甲基吡啶替换为异喹啉时, 对比催化剂 $\mathbf{4}$ 和 $\mathbf{6}$ 的催化水氧化活性和动力学研究, 也可以得到 类似的结果. 但与催化剂 $\mathbf{2}$ 和 $\mathbf{3}$ 相比, 催化剂 $\mathbf{5}$ 的反应级数降低不明显, 说明催化体系中只有一部分分子发生一级反应, 大部分分子 发生二级反应. 这说明在以化合物 $\mathbf{5}$ 为催化剂的水氧化体系中, 除了核心配体上Br的吸电子效应对催化剂机理产生影响之外, 轴 向配体的异喹啉的 $\pi-\pi$ 堆积效应也有重要影响(异哇啉的 $\pi-\pi$ 堆积效应能够促进单核催化剂发生二级反应), 并且后者产生的影响占 
主导位置, 从而导致催化剂 $\mathbf{5}$ 的反应级数降低的不明显.

关键词: 水氧化; Ru-bda型催化剂; 溴取代; 吸电子效应; 动力学研究

收稿日期: 2015-04-08. 接受日期: 2015-05-18. 出版日期: 2015-10-20.

*通讯联系人. 电话: (0411)84986249; 传真: (0411)84986245; 电子信箱: dr.gaoyan@dlut.edu.cn

\#通讯联系人. 电话: (0411)84986249; 传真: (0411)84986245; 电子信箱: liujh@dlut.edu.cn

基金来源：国家自然科学基金(20923006，21120102036，21106015和91233201); 国家重点基础研究发展计划(973计划, 2014CB239402); 中央高校基本科研业务专项基金(DUT13RC(3)103, DUT15LK08).

本文的英文电子版由Elsevier出版社在ScienceDirect上出版(http://www.sciencedirect.com/science/journal/18722067). 